\title{
Applying GRI Sustainability Reporting in the Water Sector: Evidences from an Italian Company
}

\author{
Alessia D’Andrea ${ }^{1}$ \\ ${ }^{1}$ Department of Management, Università Politecnica delle Marche, Ancona, Italy \\ Correspondence: Alessia D‘Andrea, Department of Management, Università Politecnica delle Marche, Piazzale \\ Martelli, 8 - 60121 - Ancona, Italy. Phone Number: 0039-071-220-7233.
}

Received: March 17, 2017

Accepted: April 7, 2017

Online Published: May 3, 2017

doi:10.5430/ijba.v8n3p10

URL: https://doi.org/10.5430/ijba.v8n3p10

\begin{abstract}
Sustainability reporting is considered the most applicable and reliable tool for disclosing financial and non-financial information to stakeholders and a means for strengthening company credibility. The Global Reporting Initiative (GRI) is the most common standard followed to implement and to develop sustainability reporting. Nevertheless, a few studies have focused on the real adoptability of the standard. The aim of the present study is to illustrate how GRI indicators could be applied and interpreted by managers of a water company to implement sustainability reporting. A single case study is developed to identify which factors could affect the standardized implementation of the G4 guidelines by a water utility company. The research was conducted in an Italian medium-sized enterprise, an entirely publicly owned joint-stock company under the in-house providing rules. Evidence from the case study was gathered through direct observation as well as semi-structured interviews and focus groups with the human resources responsible for the data collection. The research highlights that the process generated an internal validation of the practices carried out by the managers to achieve sustainable development. The case study presented shows that GRI Guidelines adoption is left to interpretation: certain practices and recommendations contained in the G4 implementation manual are, in fact, operationalized within the organization in consideration of the company's activities and governance. The illustration of the case study may guide practitioners in the GRI implementation process in all sectors, especially in public utilities.
\end{abstract}

Keywords: GRI guidelines, public water utilities, sustainability reporting, environmental

\section{Introduction}

Sustainability reporting is considered the most applicable and reliable tool for disseminating financial and non-financial information to internal and external stakeholders and, at the same time, a means for assessing company performance (Prado-Lorenzo et al., 2009; Lozano \& Huisingh, 2011). Some scholars have declared that sustainability reporting strengthens company credibility and allows business managers to increase their social responsibility (Dando \& Swift, 2003; Ioannou \& Serafeim; 2011; Michelon et al., 2015). Moreover, the importance of developing universal standards to meet the need for transparent and trustworthy information (Dando \& Swift, 2003; Manetti \& Becatti, 2009; Nikolaeva \& Bicho, 2011; Joseph, 2012) is widely recognized. In this field, the Global Reporting Initiative (GRI) is the most common standard followed to implement and to develop sustainability reporting (Prado-Lorenzo et al., 2009; Brown et al., 2009; Gray, 2010; Roca \& Searcy, 2012; Christofi et al., 2012; Mahoney et al., 2013; Fernandez-Feijoo et al.; 2014). However, the GRI standard has been criticized by authors who point out the dispersion of the sustainability principle (Moneva et al., 2006; Joseph, 2012) and by those who highlight that this practice can negatively influence the decision-making process (Aras \& Crowther, 2008; Morhardt, 2009). Nevertheless, a few studies have focused on the real adoptability of the standard, highlighting the possible gaps between the content of the GRI framework and its use by the company. To guide the implementation of the standard, the Global Reporting Initiative has published, over the years, some sector supplements (see for example those for firms operating in airports, construction and real estate, electric utilities, food, mining and metal, oil and gas). A notable exception is the water sector, for which no specific standard supplement has been provided. There have been, though, several valuable studies that have focused on sustainability reporting in companies operating in the water sector. Tregidga \& Milne (2006) conducted an analysis of a water company's environmental reports, covering the period from 1993 to 2003, to show the changing use of language and images over time, the impacts of these changes 
on sustainable development themes, and the implications of such constructions in term of organizational change. The study by Adams \& McNicholas (2007), instead, is focused on the process for developing a sustainability report by a water company located in Australia; the research highlights the drivers to bring about change within organizations. Larrinaga-González (2008) explores sustainability accounting and accountability practices in nine public water utilities situated in southern Spain. The findings of this research show that the stand-alone report is quite limited, but there is intense activity, including education and advertising, to raise public awareness of the importance of saving water; moreover, the accounting for the environmental performance of the water utilities is sufficiently developed. Mio (2010) analyses the factors affecting the quality of sustainability reports of listed multi-utility companies in Italy; he found that the model of materiality adopted is weak and the documents produced are still incomplete. Although these studies highlight the importance of sustainability disclosures for companies in the water sector, the process of constructing a sustainability report and the peculiarities of this business area, which could influence the adoptability of the GRI standard, are two aspects that not investigated.

The aim of the present study is to illustrate how GRI indicators could be applied and interpreted by managers of a water company to implement sustainability reporting. A single case study is developed to identify which factors could affect the standardized implementation of the G4 guidelines (GRI, 2013) by a water utility company. The research was conducted in an Italian medium-sized enterprise, C.A.D.F. SpA, an entirely publicly owned joint-stock company under the in-house providing rules. The implementation process, in compliance with GRI guidelines, lasted approximately two years (from 2014 to 2016) during which time the first report (published at the beginning of the 2015) showed a partial adoption of the list of indicators and the second report (published a year and half after) is more complete, above all for environmental information it contains, and also thanks to the addition of an external professional figure, specialized in environmental measurements, to the team.

A secondary aim of the present study is to increase the general awareness that additional guidelines for some sectors might be necessary, as stated also by Toppinen et al., 2012. Moreover, the illustration of the case study may guide practitioners in the GRI implementation process in all sectors, especially in public utilities.

\section{Literature Review}

In compliance with the legislation (Law No. 36/1994, in particular), water-related services can be entrusted to either public or private firms and these companies can be mono- or multi-utilities (Bognetti \& Robotti, 2007; Guerrini \& Campedelli, 2011; Guerrini \& Romano, 2014). Article 143 of Legislative Decree No. 152/2006 established that water utilities consist of public services covering the collection, supply, and distribution of water for civil use, sewerage and wastewater treatment; aqueducts, sewers, treatment plants, and other water infrastructures are in public ownership. The Referendum of June 2011 confirms that water resources must be publicly owned. In compliance with the same Legislative Decree No. 152/2006, the water, wastewater, and sewerage industry in Italy is organized into 'optimal geographic areas' (Ambiti Territoriali Ottimali), in the inland areas of a region. The successive Legislative Decree No. 133/2014 assigns to the Region the responsibility of selecting the service organization, of defining the optimal geographic areas, and of identifying the operator who will manage the water-related services. Within each of these areas, the water utilities are to be entrusted to a single operator (Abrate et al., 2016). The current Italian context is characterized by the co-presence of "multinational companies, large national players, local utilities and a not negligible number of specialized small municipal operators" (Abrate et al., 2016; p. 3). In particular, as stated by Guerrini et al. (2013) "publicly owned companies coexist with mixed and privately owned firms, with contracts appointed through a competitive tendering process by local water authorities" (p. 4567), where - after Legislative Decree No. 133/2014 - the local water authority is ascribable to the Region. Despite the regulation changes, it is still true, as affirmed by Guerrini et al. (2013), that in this sector there is an information asymmetry between the regulatory authority and the regulated utilities which promotes the development of a transparent reporting system to disclose companies' performance. The companies in this sector, in fact, operate according to a strong institutional and regulatory framework; the majority of their activities come under the control of a public authority, both regional and national (Mio, 2010). Consequently, their need to communicate social initiatives and correct behaviors concerning resource management is stronger than in other sectors. However, the promotion of an accountability mechanism is not only determined by the need for legitimation in the eyes of regulatory authorities, but also by the awareness that "Water is at the core of sustainable development and is critical for socio-economic development, healthy ecosystems and for human survival itself" (as recalled by United Nations, in the International Decade for Action "Water for life" 2005-2015). Regarding this point, the Resolution by the General Assembly of the United Nations No. 70/169 of 17th December 2015, which addresses the right to safe drinking water and sanitation, established that "States should increasingly pursue integrated approaches and strengthen their water resource management..." In addition, the General Assembly calls upon States "to provide for effective accountability 
mechanisms for all water and sanitation service providers to ensure that they respect human rights and do not cause human rights violations or abuses." Starting from these premises, the water utilities, above all in Italy, need to adopt accountability mechanisms in a double logic. On the one hand, the operator (to whom the management of water services is entrusted by the regulatory authority) must gain political legitimacy, as other public sector organizations do (Larrinaga-Gonzàlez, 2008); on the other hand, these companies (both public and private) have an ethical responsibility and an ecological relevance linked to sustainable development (Larrinaga-Gonzàlez, 2008) because their activities encompass social, ecological, economic, and quality issues. In this regard, environmental and social disclosures support the resolution of problems related to organizational legitimacy (Neu et al., 1998) because the voluntary nature of the reporting could enhance relationships with key stakeholders, which increases the latter's knowledge about corporate activities and results achieved. Along the same lines, Unerman et al. (2007, p.3) claim that "broader techniques of sustainability accounting and accountability have the potential to be powerful tools in the management, planning, control and accountability of organizations for their social and environmental impact." Schadewitz \& Niskala (2010) state that communication via GRI responsible reporting "is a part of a firm's communication tools to decrease information asymmetry between managers and investors" (p. 104). Moreover, as Lozano \& Huisingh (2011) assert, social reporting "is being increasingly recognized as an important driver and vehicle to engage with and to report on a company's efforts towards becoming more sustainable" (p. 105) and the GRI guideline "tends to be the most frequently used set of guidelines for SR reporting" (p. 100). Finally, Levy et al. (2010) recognize that "GRI is most important as a tool for managing corporate sustainability efforts, assessing and protecting corporate reputation, and enhancing brand values" (p. 20). The GRI has released several versions of its sustainability reporting guidelines: the first in 2000, the second in 2002, the third in 2006, the fourth in 2001, and the last in 2013. These refer to GRI standards which represent the global best practices in sustainability reporting. They are designed to be used by organizations to report on their impact on the economy, the environment, and society. The current version, called G4 guidelines, provides a set of indicators, organized in three categories: economic, environmental, and social. Each organization must publish the information related to aspects characterized by materiality, that is, relevant for stakeholders (GRI, 2013). Compared to previous versions, G4 improves the disclosures on governance, ethics and integrity, biodiversity, the supply chain, anti-corruption, and GHG emissions (Fernandez-Feijoo et al. 2014; Alonso-Almeida et al., 2014). Moreover, new indicators for measuring the reduction of energy consumption are introduced, and the G4 guidelines also provide specific indicators related to complaint mechanisms in all categories and sub-categories addressed in sustainability reporting. In addition, the most current version requires an explanation of the methodology used to measure the values and the assumptions used for calculating the indicators used (for example, for those related to eco-efficiency assessment or to the intensity of greenhouse gas emissions).

The literature review highlights, on one hand, the opportunities offered by Guidelines GRI in strengthening the corporate reputation, through a disclosure activities about the company's efforts in sustainability issues. On the other hand, the multi-utilities Italian companies, operating in the water sector, need to mechanisms to reduce the information asymmetry between the regulatory authority, which entrusts the management of the water services to the company, and the regulated utilities itself, which promotes activities in achieving the sustainable development and, at the same time, in trying to attain the socio-economic effectiveness and efficiency. Contributing at the protection of healthy ecosystems requires, for these firms, to manage activities with high environmental and social impacts. A transparent reporting system to disclose companies' performance in a responsible way may be, therefore, tool and vehicle of an organized flow of information related to these aspects. The GRI G4 Guidelines, in this respect, may enhance the practices in the accountability reporting, in providing measures and indicators able to report on the company impact on the economy, the environment, and society.

The research project - presented as a case-study - was geared toward applying the G4 guidelines to a joint-stock company operating in the Italian water industry, where the business activities present an essential environmental component and the disclosure activity is part of the strategic activities.

\section{Method}

Although several studies underscore the importance of sustainability disclosures and reporting in the water industry (Tregidga \& Milne; 2006; Adams \& McNicholas, 2007; Larrinaga-Gonzàlez; 2008; Mio, 2010), little attention has been paid to firms' implementation of the reporting process according to the GRI's G4 guidelines and the adoptability of the related set of indicators. Our study presents twin aims: firstly, to illustrate the phases of GRI adoption followed by the Italian joint-stock company C.A.D.F. SpA, and secondly, to examine the adjustments needed to calculate the set of indicators. The research is based on a qualitative embedded case study (Yin, 2009). The case study is from the product of a two-year investigation of the firm's sustainability reporting process, during which 
time the author had the opportunity to be a part of the multidisciplinary team set up for this specific purpose. In particular, the author collected data from multiple primary and secondary sources. These included participant observation (Atkinson \& Shaffir, 1998), above all during meetings and conference calls, interviews with human resources operating (Yin, 2003) in C.A.D.F. SpA at the time of the analysis, and examination of internal documentation as well as of the firm's quantitative and economic reports. The peculiarities of the Italian context and the various sources of information, either imposed or recommended by the regulatory framework, are taken into consideration in presenting the process that was implemented. At the beginning, in 2014, the primary data available in C.A.D.F.'s information system was compared with the G4 guidelines to discern the discrepancies between the indicators that were required and those that were actually available. To analyze the actual use of the G4 guidelines for the company's reporting process, a literature review related to other case studies was conducted (Adams \& Frost, 2008; Kolk,2008; Arvidsson,2010; KPMG, 2011; Bondy et al., 2012; Toppinen et al., 2013). Through various focus group meetings with the company managers (employed in commercial, administrative, technical, productive business sectors), some indicators were interpreted and the method of calculation determined. The application of the G4 at the end of the first year was only partial, as reported in C.A.D.F.'s first sustainability report. This presented a barrier that principally affected the measurement of certain environmental indicators (concerning energy consumption, emissions, waste) and, more specifically, the identification of an appropriate method of calculation. To overcome this barrier, the multidisciplinary team was enlarged the following year to include an engineer specialized in environmental matters who help to identify a suitable method for disclosing the missing information. At the same time, intra-organizational practices were adopted to cover other areas that had previously not been reported, such as aspects relative to Supplier Environmental Assessment (specifically included in the G4 guidelines). At the end of the second year, the sustainability report was more complete, but the process was still a "work in progress".

Thus, the research was planned and designed in compliance with the accountability process presented in the Copenhagen Charter (ISEA, 1999) and articulated in the following seven phases, though not always carried out consecutively:

- Definition of scope and resources

- Identification of accountability areas and themes

- $\quad$ Stakeholder mapping and definition of stakeholder engagement practices

- $\quad$ Definition of performance indicator system and monitoring of the results

- Definition of improvement target and evaluation of future actions

- Writing and publication of the social report

- $\quad$ Consultation with stakeholders

As stated as a requirement in the Copenhagen Charter, top management was continuously involved in the implementation process. This process is repeated each year.

\section{Findings}

The results of the sustainability reporting process developed in C.A.D.F. SpA, relative to the last year of the project, are presented below. Some evidence related to the first year is included only to illustrate the changing process and the evolution of the reporting.

\section{Definition of scope and resources}

Each year the sustainability reporting process started with the top management's decision to better represent the activities carried out and the results achieved as they related to the assigned objectives. The reporting is addressed to all stakeholders and, in particular, to all citizens who use the drinking water, to municipalities who own the stock capital, to the regional authority which entrusted the company with the management of the water-related services and, in general, to the community to demonstrate the actions taken to contribute to sustainable development. A specific team, composed of internal subjects (members of top and middle management) and external operators (the academic researcher, the engineer, and an organization consultant), was appointed. A deep analysis of G4 guidelines was conducted to determine which technical and human resources needed to be involved in the entire process.

\section{Identification of accountability areas and themes}

At the beginning, the identification of the accountability areas followed the list of public services cited in Article 143 of Decree No. 152/2006 regarding the collection, supply and distribution of water for civil use sewerage and wastewater treatment, and the management of aqueducts, sewers, treatment plants, and other water infrastructure. In 
addition to those, C.A.D.F. SpA also decided to report all activities carried out to sensitize the population to the proper use of water and to reducing wastage of this natural resource.

In the first year, these areas were reported considering the direct impact they had on the various categories of stakeholders. For example, the collection, supply, and distribution of water for civil use was presented to show the effects on users' needs; the management of public infrastructures was the object of the actions taken to respond to the municipalities' expectations; the social initiatives were reported in consideration of the impact on the landscape and on the common good of the community.

In the second year, the areas to report on were rethought and modified to disclose the impacts of the activities on eco-efficiency (in terms of renewable raw materials, waste treatment, energy savings), on stakeholders' social expectations (in terms of development of personnel skills, value created in the local area through jobs created and provided by local firms, and environmental promotion), and on economic results.

\section{Stakeholder mapping and definition of stakeholder engagement practices}

The definition of stakeholders was carried out in keeping with the Accountability AA1000 standard (ISEA, 1999), based on the main principle of inclusivity. The key stakeholders of C.A.D.F. SpA are: users, regional and national authorities, suppliers, and the local community. With each group, an engagement activity was implemented to identify and to understand their needs and their expectations and, at the same, time, to address the operational objectives and the activities with respect to the results of the dialogue initiatives (Thompson \& Bebbington, 2005; Bebbington, 1997, Bebbington et al., 2007). In compliance with the AA1000 Stakeholder Engagement Standard (AccountAbility, 2005), specific engagement tools were developed, i.e., a questionnaire, interviews, and a focus group (Unerman, 2000).

\section{Definition of the performance indicator system and monitoring of the results}

The method adopted for the definition of economic, environmental, and social indicators to represent objectives and to measure the results of actions undertaken was developed following the G4 guidelines and choosing which indicators to include in the reporting process. Two main criteria guided the choice: applicability (total or partial) and ability to be adapted. The first parameter was followed for the indicators that are totally or partially measurable or identifiable through narratives. The data and narrative information required for disclosing the elements included in the General Standard Disclosures of the G4 implementation Manual (strategy and analysis, organizational profile, identified material aspects and boundaries, stakeholder engagement, report profile, governance, ethics and integrity and material aspects) were considered in the category of 'total applicability'; in fact, in both years of the two-year reporting process developed at C.A.D.F. SpA, their identification was immediate and the relative sections were disclosed in the sustainability reports.

The indicators contained in the section Specific Standard Disclosures of the G4 Implementation Manual are relative to specific aspects of economic, social, and environmental nature, as described below.

Table 1. General Standard Disclosures in C.A.D.F. Sustainability Report

\begin{tabular}{|c|c|c|}
\hline G4 indicator & $\begin{array}{l}\text { Nature of } \\
\text { disclosures }\end{array}$ & Main topics, indicators or general disclosures \\
\hline $\begin{array}{l}\text { Strategy and } \\
\text { Analysis } \\
\text { G4-1, G4-2 }\end{array}$ & narrative & $\begin{array}{l}\text { Description of: } \\
\text { - Sustainable strategies: improvements of standard services; promotion of actions in } \\
\text { environmental protection and safeguard; achievement of high standards of energy } \\
\text { efficiency and progressive reduction of wastes } \\
\text { - } \quad \text { Demographic and economic framework of the local area. } \\
\text { - } \quad \text { Morphological characteristics of the local area where the aqueducts, sewers, } \\
\text { treatment plants and other water infrastructure are located. }\end{array}$ \\
\hline & quantitative & $\begin{array}{ll}- & \text { Drinking water service coverage (\%) } \\
\text { - } & \text { Compliance with laws and regulations (\%) } \\
\text { - } & \text { Sewage service coverage }(\%) \\
\text { - } & \text { Use of the purification capacity }(\%)\end{array}$ \\
\hline
\end{tabular}




\begin{tabular}{|c|c|c|}
\hline \multirow{16}{*}{$\begin{array}{l}\text { Organizational } \\
\text { Profile } \\
\text { From G4-3 to } \\
\text { G4-16 }\end{array}$} & \multirow[t]{10}{*}{ narrative } & - Name of the organization: C.A.D.F. SpA “L’Acquedotto del Delta” \\
\hline & & - Water-related services: collection, supply and distribution of water for civil use \\
\hline & & - Location of the organization's headquarters \\
\hline & & - Local area corresponding to the urban and extra-urban area of 13 municipalities \\
\hline & & - Water utilities (provided to citizens geographically located in the local area); \\
\hline & & - Specific Physical-chemical-bacteriological tests (on request by private customers) \\
\hline & & - Publicly owned joint-stock company under the in-house providing rules Risk \\
\hline & & - Assessment policies and actions \\
\hline & & - Description of the supplying process and the water collection \\
\hline & & $\begin{array}{l}\text { - Reference to ISO 9001: 2008, Regulation of the relationship between operator and } \\
\text { users, Charter of Services, list of industry associations }\end{array}$ \\
\hline & \multirow[t]{6}{*}{ quantitative } & - Net sales; \\
\hline & & - Volumes of drinking water - cubic meters (total and per capita) \\
\hline & & - Number of users served with water utilities in each municipality \\
\hline & & - Volume of treated water in depuration plants - cube meters \\
\hline & & - Number of employees (total and by gender, professional status, type of contract) \\
\hline & & - Members of the labour unions ( $\%$ of employees) \\
\hline $\begin{array}{l}\text { Material } \\
\text { Aspects and } \\
\text { Boundaries } \\
\text { From G4- } 17 \\
\text { to G4-23 }\end{array}$ & narrative & $\begin{array}{l}\text { Material Aspects of the report (mainly: quality of water, safeguard of the natural } \\
\text { resources, effectiveness), restatements of information and significant changes respect } \\
\text { to previous report disclosed in the methodology section. }\end{array}$ \\
\hline \multirow{3}{*}{$\begin{array}{l}\text { Stakeholder } \\
\text { Engagement } \\
\text { From G4-24 } \\
\text { to G4-27 }\end{array}$} & \multirow[t]{3}{*}{ narrative } & $\begin{array}{l}\text { - Definition of the stakeholder map (with description of the relationship between the } \\
\text { company and its stakeholder) }\end{array}$ \\
\hline & & $\begin{array}{l}\text { - Stakeholder engagement tools: questionnaire to supplier and customers; interviews } \\
\text { to local authorities; customer satisfaction survey to users }\end{array}$ \\
\hline & & - Reporting of main results with evidences about the key topics and concerns \\
\hline \multirow{6}{*}{$\begin{array}{l}\text { Report Profile } \\
\text { From G4-28 } \\
\text { to G4-33 }\end{array}$} & \multirow[t]{6}{*}{ narrative } & - Reporting period: 2015 \\
\hline & & - Date of most recent previous report: from 2010 \\
\hline & & - Reporting cycle: annual \\
\hline & & - Contact points for questions regarding the report: mail, company address, phone \\
\hline & & - GRI content index reported (with listed the set of indicators adopted) \\
\hline & & - External assurance process not carried out \\
\hline \multirow{6}{*}{$\begin{array}{l}\text { Governance } \\
\text { From G4-34 } \\
\text { to G4-55 }\end{array}$} & \multirow[t]{3}{*}{ narrative } & $\begin{array}{l}\text { - Governance structure of the organization (highest governance body; executives and } \\
\text { non-executives); organization chart; }\end{array}$ \\
\hline & & - References to the Company Statute and Regulatory framework; \\
\hline & & - Brief description of remuneration policies (by professional status, type of contract) \\
\hline & \multirow[t]{3}{*}{ quantitative } & - Highest governance body by gender, professional status, type of contract \\
\hline & & - Number of shareholders' meeting per year. \\
\hline & & $\begin{array}{l}\text { - Variable and fixes remuneration and awards for the highest governance body and } \\
\text { senior executives (total and \%) }\end{array}$ \\
\hline
\end{tabular}


Ethics and narrative References to the Ethic Code and Code of Conduct

Integrity

From G4-56

to G4-58

\section{Economic indicators}

Specifically, all economic indicators were measured and later disclosed in the reports, but some indicators were adapted taking into account that C.A.D.F SpA is an in-house provider of public services; the ownership of the infrastructure is public and, consequently, C.A.D.F. SpA pays rent; the company receives capital grants for new investments or for the maintenance of infrastructures.

Table 2. Economic Indicators in C.A.D.F. Sustainability Report

\begin{tabular}{|c|c|c|}
\hline $\begin{array}{l}\text { G4 } \\
\text { indicator }\end{array}$ & $\begin{array}{l}\text { Nature of } \\
\text { disclosures }\end{array}$ & Main topic, indicator or general disclosure \\
\hline EC1 & quantitative & $\begin{array}{ll}\text { - } & \text { Net operating income (three-year trend) } \\
\text { - } & \text { Added value (three-year trend) } \\
\text { - } & \text { Economic value distributed per stakeholder (municipalities, employees, suppliers, } \\
& \text { public administration, community and natural environment) }\end{array}$ \\
\hline EC2 & quantitative & $\begin{array}{l}\text { Investments and expenditures, also for maintenance service connected with } \\
\text { consequences of climatic phenomena }\end{array}$ \\
\hline EC3 & narrative & Characteristics of plan's pension (included supplementary pension funds) \\
\hline EC4 & quantitative & Amount of capital grants for investments and maintenances \\
\hline EC5 & quantitative & $\begin{array}{l}\text { Average wage by contractual level and by gender - in Euros and \%; } \\
\text { Salary difference between men and women }(\%)\end{array}$ \\
\hline EC6 & quantitative & Not disclosed \\
\hline EC7; EC8 & quantitative & $\begin{array}{l}\text { - } \quad \text { Value of civil and building works completed - in euros (three-year trend) } \\
\text { - } \quad \text { Value of civil and building works in progress - in euros (three-year trend) } \\
\text { - } \quad \text { Investment value per capita (user) - in euros (three-year trend) }\end{array}$ \\
\hline EC9 & quantitative & $\begin{array}{l}\text { - } \% \text { local suppliers (local = province) on total suppliers (considering the amount of } \\
\text { the supplying costs) }\end{array}$ \\
\hline
\end{tabular}

\section{Social indicators.}

The Social Category includes the sub-Categories: Labor Practices and Decent Work, Human Rights, Society, and Product Responsibility. In the sub-category, Labor Practices and Decent Work, the measurement of indicators linked to Supplier Assessment required the implementation of an internal process to define the screening criteria and, subsequently, dialogue activities were undertaken with suppliers to collect information about labor criteria adopted by them; the collection of this kind of information ended in 2016. The remainder of the information needed in this sub-category was collected and reported. The sub-category Human Rights included the following issues: nondiscrimination, gender equality, freedom of association, collective bargaining, child labor, forced or compulsory labor, and indigenous rights. Italian legislation guarantees the rights linked to these issues and a specific cross reference to the legislative norms were carried out. The adoption of indicators recommended in the category Society was total, although C.A.D.F. SpA must include the social issues (and also the environmental issues concerning the next aspect) in the dialogue with suppliers. Finally, because of the nature of the (water-related products and services delivered, the information about labelling required in the subcategory Product Responsibility was not collected and disclosed. 
Table 3. Social Indicators in C.A.D.F. Sustainability Report

\begin{tabular}{|c|c|c|}
\hline G4 indicator & $\begin{array}{l}\text { Nature of } \\
\text { disclosures }\end{array}$ & Main topic, indicator, or general disclosure \\
\hline \multirow[t]{3}{*}{$\begin{array}{l}\text { From LA1 to } \\
\text { LA13 }\end{array}$} & quantitative & $\begin{array}{l}\text { - Total number and rates of employees by gender, seniority, educational qualification, } \\
\text { professional status, type of contract, territorial origin; } \\
\text { - Composition of governance bodies by gender } \\
\text { - Absenteeism ratio } \\
\text { - Fixed and variable remuneration (\% on total) } \\
\text { - Number of employees with part-time contract or with flexible hours } \\
\text { - Number of parental leave (by gender) } \\
\text { - Duration of parental leave taken (total hours and per capita) } \\
\text { - On-the-job injury ratio } \\
\text { - Salary difference between men and women }(\%)\end{array}$ \\
\hline & narrative & $\begin{array}{l}\text { - Benefits provided to employees } \\
\text { - Description of the occupational health and safety programs } \\
\text { - Compliance with the regulatory framework (Legislative Decree no. 81/08) } \\
\text { - Presence of a health and safety committees } \\
\text { - Regular updating of the Risk Assessment Document } \\
\text { - Initiatives to inform employees (newsletters, intranet, periodic meetings) } \\
\text { - Description of training and education policies (development plans, learning programs) }\end{array}$ \\
\hline & in progress & Supplier Assessment for Labor Practices - Labor Practices Grievance Mechanisms \\
\hline $\begin{array}{l}\text { Human rights } \\
\text { From HR1 to } \\
\text { HR12 }\end{array}$ & narrative & Compliance with the regulatory framework (National and European laws) \\
\hline \multirow[t]{2}{*}{$\begin{array}{l}\text { From SO1 to } \\
\text { SO11 }\end{array}$} & quantitative & $\begin{array}{l}\text { Social initiatives } \\
\text { - Number of guests to "C.E.A. La Fabbrica dell'Acqua" (Environmental Education } \\
\text { Center) - by typology (students, teachers, others) } \\
\text { - Number of projects and didactic activities promoted by "C.E.A. La Fabbrica } \\
\text { dell'Acqua" (Environmental Education Center) } \\
\text { - Financial contributions for social initiatives (in euros) } \\
\text { Anti-corruption } \\
\text { - Number of processes assessed for risks related to corruption } \\
\text { - Number of confirmed cases of corruption (and actions) } \\
\text { - Level of residual risk of assessed processes } \\
\text { - \% of employees to which the organization's anti-corruption policies were } \\
\text { communicated } \\
\text { - Number of workers who have received training on anti-corruption } \\
\text { Other topics: } \\
\text { - Political contributions: not verified during the reporting period } \\
\text { - Monetary value of significant fines and total number of non-monetary sanctions for } \\
\text { non-compliance with laws and regulations: not verified during the reporting period }\end{array}$ \\
\hline & narrative & $\begin{array}{l}\text { - Description of objectives and activities promoted and developed by “C.E.A. La } \\
\text { Fabbrica dell'Acqua" (Environmental Education Center) }\end{array}$ \\
\hline
\end{tabular}


- Description of objectives and activities of international initiatives in developing countries

- Description of Anti-corruption policies

- Declaration of compliance to legislation (for topics related to anti-corruption and competitive behaviour)

\begin{tabular}{|c|c|c|}
\hline & in progress & $\begin{array}{l}\text { Supplier Assessment for Impacts on Society } \\
\text { Grievance Mechanisms for Impacts on Society }\end{array}$ \\
\hline $\begin{array}{l}\text { Product } \\
\text { responsibility } \\
\text { From PR1 to } \\
\text { PR9 }\end{array}$ & $\begin{array}{l}\text { narrative } \\
\text { and } \\
\text { quantitative }\end{array}$ & $\begin{array}{l}\text { - Main parameters analyzed and monitored to verify the quality of drinking water and } \\
\text { the water in sewage plant } \\
\text { - Results of checks carried out by local health authority on drinking water and the water } \\
\text { in sewage plant } \\
\text { - Results of surveys measuring customer satisfaction } \\
\text { - Description of marketing communication tools and customer's services. } \\
\text { - Monetary value of significant fines for non-compliance with laws and regulations } \\
\text { concerning the provision and use of products and services: not verified during the } \\
\text { reporting period }\end{array}$ \\
\hline
\end{tabular}

\section{Environmental indicators.}

This Category covers impacts related to inputs (such as energy and water), outputs (such as emissions, effluents and waste), biodiversity, transport, and product and service-related impacts, as well as environmental compliance and expenditures (GRI G4 Implementation Manual, 2013, p. 84). All of the environmental indicators were considered in the sustainability reporting process of C.A.D.F. SpA because the natural resource, i.e., water, mainly, is both the input and the output of its business activities. For this reason, some indicators included in this category were adjusted or, rather, interpreted with this aspect in mind. This was verified for the data required in the sections Water and Effluents and Waste. Table 1 shows the interpretation carried out. Moreover, for the Environmental Indicators category, the entire process highlighted that

- to disclose information recommended in the sub-section Biodiversity, a continuous interaction with local public entities was required in order to obtain the geographical location of protected areas as well as the conservation list for fauna and flora species within the same areas. This information was linked to the impact of operational sites in the identified protection area and the specific actions carried out by C.A.D.F. SpA to safeguard natural resources and habitats;

$\circ \quad$ to calculate the Emissions indicators and the Energy Intensity Ratio, an external engineer was needed to support the technical professionals who worked in C.A.D.F. SpA; specifically, the support concerned the identification of a mathematical formula to calculate the energy indicators and the gas emissions parameters. In this case, the process was completed during the second year of the research project.

Table 4. Environmental Indicators in C.A.D.F. Sustainability Report

\begin{tabular}{llll}
\hline G4 indicator & $\begin{array}{l}\text { Nature of } \\
\text { disclosures }\end{array}$ & Main topic, indicator, or general disclosure \\
\hline Materials & quantitative & - & Raw materials (by weight) used in the three sectors: aqueducts, sewers, \\
EN1; EN2 & & $\begin{array}{l}\text { treatment plant (tons/year) } \\
\text { Raw materials (renewable and non-renewable) used in the three sectors: } \\
\end{array}$ & aqueducts, sewers, treatment plants (tons/year) \\
\hline Energy & quantitative & - & $\begin{array}{l}\text { Indirect energy consumption (purchased in the free market) by services } \\
\text { typology (kwh and MegaJoule) }\end{array}$ \\
From EN3 to & & $-\begin{array}{l}\text { \% indirect energy consumption (provided by renewable sources) on total } \\
\text { indirect energy consumption }\end{array}$ \\
EN7 & &
\end{tabular}


- indirect energy costs by services typology (in euros)

- direct energy consumption by energy source typology (Methane, LPG, Fuel, Diesel) converted in MegaJoule

- Total energy consumption

- Energy intensity (one): energy consumption (during the aqueduct activities)/ water withdrawn and pumped in water supply network ( $\mathrm{kwh} /$ cubic meters)

- Energy intensity (two): energy consumption (during the aqueduct activities)/ water distributed (kwh/cubic meters)

- Energy consumption outside of the organization: not disclosed

\begin{tabular}{|c|c|c|}
\hline $\begin{array}{l}\text { Water } \\
\text { EN8; EN9; } \\
\text { EN10 }\end{array}$ & quantitative & $\begin{array}{l}\text { Cubic meters of water withdrawn from alluvial wells and rivers (utilized in } \\
\text { aqueducts) } \\
\text { - Percentage and total volume (cubic meters) of wastewater treated and returned } \\
\text { to the environment (put through a purification plant) } \\
\text { - Total volume (cubic meters) of water supplied by sector (aqueducts, } \\
\text { purification plant, sewage system) per municipality }\end{array}$ \\
\hline $\begin{array}{l}\text { Biodiversity } \\
\text { From EN11 to } \\
\text { EN14 }\end{array}$ & narrative & $\begin{array}{l}\text { - Description of localization (and size) of managed lands in protected areas and } \\
\text { areas of high biodiversity value } \\
\text { - Description of company activities to preserve protected areas and areas of high } \\
\text { biodiversity value } \\
\text { - Description of national conservation list species with habitats in areas affected } \\
\text { by operations }\end{array}$ \\
\hline $\begin{array}{l}\text { Emissions } \\
\text { From EN15 } \\
\text { to EN21 }\end{array}$ & quantitative & $\begin{array}{l}\text { - Gas emission by scope (in compliance with Greenhouse Gas (GHG) Protocol) - } \\
\text { tons of CO2e. The annual emission factor (average) used is indicated (source: } \\
\text { Intergovernmental Panel on Climate Change - IPCC) } \\
\text { - Gas emissions (Carbon dioxide - CO2; Nitrogen oxides - Nox; Sulphur oxides - } \\
\text { Sox; Volatile organic compounds - VOC; Particulate - PTS; Carbon Monoxide } \\
\text { - CO) - tons }\end{array}$ \\
\hline $\begin{array}{l}\text { Effluents and } \\
\text { Waste } \\
\text { From EN22 to } \\
\text { EN26 }\end{array}$ & quantitative & $\begin{array}{l}\text { - Number of purification plants by potential classes and related wastewater } \\
\text { volumes treated and returned to the environment } \\
\text { - Number of purification plants by potential classes and relative quantities of COD } \\
\text { (chemical oxygen demand) removed / Phosphorus removed/ Nitrogen removed/ } \\
\text { Suspended solids removed } \\
\text { - Special waste (sludge, sand) produced in the purification services } \\
\text { - Hazardous waste (tons / year) }\end{array}$ \\
\hline $\begin{array}{l}\text { Products and } \\
\text { Services } \\
\text { EN27; (EN28 } \\
\text { not applicable) }\end{array}$ & $\begin{array}{l}\text { narrative } \\
\text { and } \\
\text { quantitative }\end{array}$ & $\begin{array}{l}\text { - Initiatives to reduce water leaks and waste } \\
\text { - benchmarks on the linear losses - AGFAM Studio and PTA } 41 \\
\text { - Initiatives to reduce the misuse of potable water } \\
\text { - Tools to support "service continuity" and the reduction of leakage (remote } \\
\text { control and remote control; computer model and districts) }\end{array}$ \\
\hline $\begin{array}{l}\text { Compliance } \\
\text { EN } 29\end{array}$ & & not verified during the reporting period \\
\hline $\begin{array}{l}\text { Transport } \\
\text { EN30 }\end{array}$ & narrative & Description of means of transport \\
\hline $\begin{array}{l}\text { Overall } \\
\text { EN31 }\end{array}$ & quantitative & Maintenance works on the sewer and water infrastructures (number and duration) \\
\hline
\end{tabular}




Supplier Environmental in progress

Assessment; Environmental

Grievance Mechanisms

\section{Definition of improvement target and evaluation of future actions}

The results of the dialogue tools, the analyzed data and narrative information, calculated starting from the available information system and the interaction with stakeholders, were discussed with the top and middle managers. The focus groups engaged in a reflection on which strategies (and relative actions) should be developed in order to achieve the goal of sustainability and safeguarding of the water supply.

Writing and publication of the social report

In this phase, the economic, physical, and qualitative information was presented in a formal document. The social report (year 2015) was divided into sections. The main topics in each section are summarized below.

- THE IDENTITY OF THE COMPANY. Description of the historical stages, the mission, the vision and the values that guide the organization, the governance, the strategies and the stakeholder map.

- THE WATER CYCLE. Description of the various stages of the water service management (collection, water treatment and sewerage system), with the report and explanation of the performance results achieved.

- ECO-ENERGY RESPONSIBILITY. Description of the environmental impact (specifically related to eco-sustainable energy) of the activities and the choices made in order to prevent pollution and to promote the responsible use of materials and water resources.

- SOCIAL RESPONSIBILITY. Qualitative and quantitative description of the social initiatives that CADF SpA promoted and the results that the company has achieved in managing relationships with employees, suppliers, and the community.

- THE MAIN FINANCIAL RESULTS. Representation of the main economic and financial results of 2015.

- THE IMPROVEMENT TARGETS. Description of the improvement objectives that the company will strive to achieve in the short and in the medium-to-long term.

\section{Consultation with stakeholders}

The result of the sustainability reporting process (the social report) was transmitted to a wide range of stakeholders, through web tools, multi-stakeholder forums and conferences, public meetings, and the press (Unerman \& Bennet, 2004; Adams \& Frost, 2006; Gallhofer \& Haslam, 2006; Sikka, 2006).

During this process, a debate was initiated among some key stakeholders (with human resources, political institutions, and the regional authorities). The debate shed light on the gap in information about some specific activities and brought forth some useful suggestions for the next sustainability reports.

\section{Discussion}

The exploration of sustainability reporting in the water sector was accomplished by presenting the results of the implementation process conducted in an in-house provider of water-related services in Italy. Evidence from the case study was gathered through direct observation as well as semi-structured interviews and focus groups with the human resources responsible for the data collection. The research highlights some benefits of using the GRI-G4 guidelines, on the one hand, but, at the same time, points out some obstacles in its application. Firstly, the process generated an internal validation of the practices carried out by the managers to achieve sustainable development, particularly by shaping socially responsible behaviors in the firm; the Global Reporting Initiative (GRI) confirmed its role as a vehicle for raising awareness and improving corporate sustainability reporting (Veleva et al., 2003). In the water sector, moreover, there continues to be a need to share methods and data. In fact, within the company, and in these kinds of firms in general, monitoring - subjected to a strong regulation framework and control (Guerrini et al., 2011) - of the planned strategic objectives and of the actual results obtained should be increased, in order to achieve the aims of sustainability reporting.

Linked to this consideration, social reporting prevents companies that operate in the water utility sector from losing credibility (Ioannou \& Serafeim, 2011). The use of GRI guidelines, recognized as "a broadly applicable and reliable set of standards used to communicate with internal and external stakeholders" (Alonso-Almeida et al., 2014), allows these organizations to communicate how social initiatives are managed (Mio, 2010). At the same time, its adoption is 
left to interpretation. The case study presented in this paper shows that certain practices and recommendations contained in the G4 implementation manual are, in fact, operationalized within the organization in consideration of the company's activities and governance.

Further research might address, firstly, the issue of how to increase knowledge on implementing the GRI guidelines in operative realities, above all in public utility sectors and in those with very strong regulatory frameworks; secondly, further investigations could demonstrate whether the overlapping of input indicators and output indicators is a peculiarity of the reporting process carried out by water companies or whether it is possible to extend this consideration to all companies operating in the field of natural resource management.

\section{References}

Abrate, G., Bruno, C., Erbetta, F., \& Giolitti, A. (2016, June). Efficiency in the Consolidation of the Italian Water Sector. Water Resources Management. http://dx.doi.org/10.1007/s11269-016-1376-9

Adams, C. A., \& Frost, G. R. (2008). Integrating sustainability reporting into management practices. Accounting Forum, 32(4), 288-302. http://dx.doi.org/10.1016/j.accfor.2008.05.002

Adams, C. A., \& McNicholas, P. (2007). Making a difference: sustainability reporting, accountability and organisational change. Accounting, Auditing and Accountability Journal, 20(3), 382-402. http://dx.doi.org/10.1108/09513570710748553

Alonso-Almeida, M., Llach, J., \& Marimon, F. (2014). A Closer Look at the 'Global Reporting Initiative' Sustainability Reporting as a Tool to Implement Environmental and Social Policies: A Worldwide Sector Analysis. Corporate Social Responsibility and Environmental Management, 21, 318-335 http://dx.doi.org/10.1002/csr.1318

Aras, G., \& Crowther, D. (2008). Corporate sustainability reporting: a study in disingenuity?. Journal of Business Ethics, 87(1), 279-288. http://dx.doi.org/10.1007/s10551-008-9806-0

Arvidsson, S. (2010). Communication of corporate social responsibility: A study of the views of management teams in large companies. Journal of Business Ethics, 96(3), 339-354. http://dx.doi.org/ 10.1007/s10551-010-0469-2

Atkinson, A. A., \& Shaffir, W. (1998). Standards for field research in management accounting. Journal of Management Accounting Research, 10, 41-68.

Bebbington, J. (1997). Engagement, education and sustainability A review essay on environmental accounting. Accounting, Auditing \& Accountability Journal, 10(3). http://dx.doi.org/10.1108/09513579710178115

Bebbington, J., Brown, J., Frame, B., \& Thomson, I. (2007). Theorizing engagement: the potential of a critical dialogic approach. Accounting, Auditing \& Accountability Journal, 20(3), 356-381. http://dx.doi.org/10.1108/09513570710748544.

Bognetti, G., \& Robotti, L. (2007). The provision of local public services through mixed enterprises: the Italian case. Annals of Public and Cooperative Economics, 78 , 415-437. http://dx.doi.org/10.1111/j.1467-8292.2007.00340.x

Bondy, K., Moon, J., \& Matten, D. (2012). An institution of corporate social responsibility (CSR) in multi-national corporations (MNCs): Form and implications. Journal of Business Ethics, 111(2), 281-299. http://dx.doi.org/10.1007/s10551-012-1208-7

Brown, H. S., de Jong, M., \& Levy, D. L. (2009). Building institutions based on information disclosure: lessons from GRI's sustainability reporting. Journal of Cleaner Production, 17(6), 571-580. http://dx.doi.org/10.1016/j.jclepro.2008.12.009

Christofi, A., Christofi, P., \& Sisaye, S. (2012). Corporate sustainability: historical development and reporting practices. Management Research Review, 35(2), 157-172. http://dx.doi.org//10.1108/01409171211195170.

Dando, N., \& Swift, T. (2003). Transparency and assurance. Journal of Business Ethics, 44(2), 195-200. http://dx.doi.org/10.1023/A:1023351816790

Fernandez-Feijoo, B., Romero, S., \& Ruiz, S. (2014, October). Commitment to Corporate social responsibility measured through global reporting initiative reporting: factors affecting the behavior of companies. Journal of Cleaner Production, 81(15), 244-254. http://dx.doi.org/10.1016/j.jclepro.2014.06.034 
Gallhofer, S., Haslam, J., Monk, E., \& Roberts, C. (2006). The emancipatory potential of online reporting: The case of counter accounting, Accounting, Auditing \& Accountability Journal, 19(5), 681-718. http://dx.doi.org/10.1108/09513570610689668

Gray, R. (2010). Is accounting for sustainability actually accounting for sustainability and how would we know? An exploration of narratives of organisations and the planet. Accounting, Organizations and Society, 35(1), 47-62. http://dx.doi.org/10.1016/j.aos.2009.04.006

GRI. (2013). Sustainability reporting guidelines-G4, Retrieved from https://www.globalreporting.org/resourcelibrary/GRIG4-Part1-Reporting-Principles-and-Standard-Disclosures.p df

Guerrini, A., \& Romano, G. (2014). Water Management in Italy, Part of the series SpringerBriefs in Water Science and Technology, 5-15. http://dx.doi.org/10.1007/978-3-319-07818-2_2

Guerrini, A., Romano, G., \& Campedelli, B. (2011). Factors affecting the performance of water utility companies. International Journal of Public Sector Management, 24(6), 543-566. http://dx.doi.org/10.1108/09513551111163657

Guerrini, A., Romano, G., \& Campedelli, B. (2013). Economies of scale, scope, and density in the Italian water sector: A two-stage data envelopment analysis approach. Water Resources Management, 27(13), 4558-4578. http://dx.doi.org/10.1007/s11269-013-0426-9

Ioannou, I., \& Serafeim, G. (2011). The consequences of mandatory corporate sustainability reporting. Harvard Business School Research Working Paper 11-100. Retrieved from http://www.hbs.edu/faculty/Publication\%20Files/11-100_7f383b79-8dad-462d-90df-324e298acb49.pdf

Joseph G. (2012). Ambiguous but tethered: An accounting basis for sustainability reporting. Critical Perspectives on Accounting, 23(2), 93-106. http://dx.doi.org/ 10.1016/j. cpa.2011.11.011

Kolk, A. (2008). Sustainability, accountability and corporate governance: Exploring multinationals' reporting practices. Business Strategy and the Environment, 17(1), 1-15. http://dx.doi.org/10.1002/bse.511

KPMG. (2011). KPMG international survey of corporate responsibility reporting 2011. Retrieved from http://www.kpmg.com/Ca/en/IssuesAndInsights/ArticlesPublications/Documents/CSR\%20Survey\%202011.pdf

Larrinaga-Gonzàlez, C. (2008). Sustainability accounting and accountability in public water companies. Working papers series. Retrieved from www.upo.es/serv/bib/wpbsad/bsad0805.pdf

Levy, D., Brown, H., \& de Jong, M. (2010). The contested politics of corporate governance. The case of the Global Reporting Initiative. Business and Society, 49(1), 88-115. http://dx.doi.org/10.1177/0007650309345420

Lozano, R., \& Huisingh, D. (2011). Inter-linking issues and dimensions in sustainability reporting. Journal of Cleaner Production, 19, 99-107. http://dx.doi.org/10.1016/j.jclepro.2010.01.004

Mahoney, L. S., Thorne, L., Cecil, L., \& LaGore, W. (2013). A research note on standalone corporate social responsibility reports: Signaling or greenwashing?. Critical Perspectives on Accounting, 24(4-5), 350-359. http://dx.doi.org/10.1016/j.cpa.2012.09.008

Manetti, G., \& Becatti, L. (2009). Assurance Services for Sustainability Reports: Standards and Empirical Evidence. Journal of Business Ethics, 87(1), 289-298. http://dx.doi.org/10.1007/s10551-008-9809-x

Michelon, G., Pilonato, S., \& Ricceri, F. (2015). CSR reporting practices and the quality of disclosure: An empirical analysis. Critical Perspectives on Accounting, 33, 59-78. http://dx.doi.org/10.1016/j.cpa.2014.10.003

Mio, C. (2010). Corporate social reporting in Italian multi-utility companies: an empirical analysis. Corporate Social Responsibility and Environmental Management, 17, 247-271. http://dx.doi.org/ 10.1002/csr.213

Moneva, J. M., Archel, P., \& Correa, C. (2006). GRI and the camouflaging of corporate unsustainability. Accounting Forum, 30, 121-137. http://dx.doi.org/10.1016/j.accfor.2006.02.001

Morhardt, J. E. (2009). General disregard for details of GRI human rights reporting by large corporations. Global Business Review, 10(2), 141-158. http://dx.doi.org/10.1177/097215090901000201

Neu, D., Warsame, H., \& Pedwell, K. (1998). Managing public impressions: environmental disclosures in annual reports. Accounting, Organizations and Society, 23(3), http://dx.doi.org/10.1016/S0361-3682(97)00008-1. 
Nikolaeva, R., \& Bicho, M. (2011). The role of institutional and reputational factors in the voluntary adoption of corporate social responsibility reporting standards. Journal of the Academy of Marketing Science, 39(1), 136-157. http://dx.doi.org/10.1007/s11747-010-0214-5

Prado-Lorenzo, J. M., Gallego-Alvarez, I., \& Garcia-Sanchez, I. M. (2009). Stakeholder engagement and corporate social responsibility reporting: the ownership structure effect. Corporate Social Responsibility and Environmental Management, 16, 94-107. http://dx.doi.org/10.1002/csr.189

Roca, L. C., \& Searcy, C. (2012). An analysis of indicators disclosed in corporate sustainability reports. Journal of Cleaner Production, 20(1), 103-108. http://dx.doi.org/10.1016/j.jclepro.2011.08.002

Schadewitz, H., \& Niskala, M. (2010). Communication via Responsibility Reporting and Its Effect on Firm Value in Finland. Corporate Social Responsibility and Environmental Management, 17, 96-106. http://dx.doi.org/10.1002/csr.234

Sikka, P. (2006). The internet and possibilities for counter accounts: some reflections. Accounting, Auditing \& Accountability Journal, 19(5), 759-769, http://dx.doi.org/10.1108/09513570610689686.

Thomson, I., \& Bebbington, J. (2005). Social and environmental reporting in the UK: a pedagogic evaluation. Critical Perspectives on Accounting, 16(5), 507-533. http://dx.doi.org/10.1016/j.cpa.2003.06.003

Toppinen, A., \& Korhonen-Kurki, K. (2013). Global Reporting Initiative and social impact in managing corporate responsibility: A case study of three multinationals in the forest industry. Business Ethics: A European Review, 22(2), 202-217. http://dx.doi.org/10.1111/beer.12016

Toppinen, A., Li, N., Tuppura, A., \& Xiong, Y. (2012). Corporate Responsibility and Strategic Groups in the Forest-based Industry: Exploratory Analysis based on the Global Reporting Initiative (GRI) Framework. Corporate Social Responsibility and Environmental Management, 19, 191-205. http://dx.doi.org/10.1002/csr.256

Tregidga, H., \& Milne, M. (2006). From Sustainable Management to Sustainable Development: A Longitudinal Analysis of a Leading New Zealand Environmental Reporter. Business Strategy and the Environment, 15, 219-241. http://dx.doi.org/10.1002/bse.534

Unerman, J., Bebbington, J., \& O’Dwyer, B. (2007). Sustainability Accounting and Accountability. London: Routledge.

Unermann, J. (2000). Methodological issues. Reflections on quantification in corporate social reporting content analysis. Accounting, Auditing \& Accountability Journal, 13(5), 667-681. http://dx.doi.org/10.1108/09513570010353756

Veleva, V., Hart, M., Greiner, T., \& Crumbley, C. (2003). Indicators for measuring environmental sustainability: A case study of the pharmaceutical industry. Benchmarking: An International Journal, 10(2), 107-119. http://dx.doi.org/10.1108/14635770310469644

Yin, R. K. (2003). Case Study Research: Design and Methods (3th ed.). Thousand Oaks, CA: Sage.

Yin, R. K. (2009). Case study research: Design and methods (4th ed.). Thousand Oaks, CA: Sage. 